\title{
Rupture of Renal Pelvis in Occult Hydronephrosis after a Simple Football Injury: A Case Report
}

\author{
Okült Hidronefrozda Basit Bir Futbol İnjurisine Bağlı Renal Pelvis Rüptürü: \\ Olgu Sunumu
}

Necdet Poyraz', Abdussamet Batur'1, Mehmet Balasar²

'Department of Radiology, Meram Faculty of Medicine, Necmettin Erbakan University, Konya, Turkey ${ }^{2}$ Department of Urology, Meram Faculty of Medicine, Necmettin Erbakan University, Konya, Turkey

\section{ABSTRACT}

Introduction: Isolated injury to the upper urinary tract following blunt abdominal trauma is very rare. However, a preexisting renal abnormality will increase the risk of rupture.

Case Report: We report a case with previously asymptomatic and undetected congenital pelviureteric junction obstruction who first presented with acute abdomen following trauma.

Conclusion: A simple abdominal trauma with underlying renal abnormalities can cause serious problems. Computed tomography $(\mathrm{CT})$ is the primary imaging modality in the urinary tract trauma.

Keywords: Renal pelvis rupture, trauma, occult hydroephrosis, CT Received: 10.02.2013 Accepted: 20.03.2013

\section{ÖZET}

Giriş: Künt abdominal travma sonrası üst üriner sistemin izole yaralanması oldukça nadirdir. Fakat önceden varolan renal anomali durumunda meydana gelen travmalarda rüptür riski artar.

Olgu Sunumu: Bu yazımızda daha önce tesbit edilmemiş asemptomatik üreteropelvik bileşkede darlığı olan bir çocukta, travma sonrası ortaya çıkan akut batın tablosunu sunuyoruz.

Sonuç: Basit bir batın travması altta yatan böbrek anomalisi nedeniyle ciddi problemlere neden olabilir. BT üriner sistem travmalarında primer görüntüleme yöntemidir.

Anahtar Kelimeler: Böbrek pelvis rüptürü, travma, okült hidronefroz, BT

Geliş Tarihi: 10.02.2013 Kabul Tarihi: 20.03.2013

\section{Introduction}

Perforation of the renal pelvis following blunt abdominal trauma is a rare and potentially dangerous condition. Early diagnosis is very important, otherwise a series of problems may develop such as urinoma, urosepsis, abscess, infection etc. Renal injury caused by blunt abdominal trauma is approximately twice as common in children as adults and is often more severe. Children have relatively larger and more lobulated kidneys, less perirenal fat, and decreased muscle and bony protection. The presence of an abnormality further predisposes the kidney to severe injury even in the setting of relatively minor trauma. The most common preexisting anomalies are cyst and tumor, horseshoe or ectopic kidney, and hydronephrosis. Urethral injury associated with blunt trauma typically occurs at the pelviureteric junction (1). We report a case with previously asymptomatic and undetected congenital ureteropelvic junction (UPJ) obstruction who first presented with acute abdomen following trauma.

\section{Case Report}

A previously-well 17-year-old boy was admitted to the emergency department with flank pain which developed after his friend's knee hit his right flank while playing football. Clinically, he was stable except for tenderness and guarding over his entire abdomen. There were no external injuries. Hematological and renal function parameters were normal. Urinalysis revealed no hematuria. 
An ultrasonography (US) examination showed a hydronephrotic right kidney and large perinephric fluid collection. Computed tomography (CT) demonstrated severe pelvicalyceal dilatation and a thinned cortex suggestive of right chronic hydronephrosis with a large urinoma due to pelvic rupture (Figure 1). CT scan showed no parenchymal laceration and ureteral dilatation. The left kidney was normal.

Following this, a percutaneous nephrostomy catheter was placed into the renal pelvis. Antegrade pyelography (AGP) performed through the nephrostomy catheter showed immense extravasation of contrast from the UPJ (Figure 2). He was managed conservatively with bed rest and frequent serum haemoglobin monitoring. On follow-up, there was no deterioration of vital signs and hemoglobin value. Magnetic Resonance Imaging (MRI) scan was performed one month later. It showed resorption of the urinoma in the right perirenal space (Figure 3). The patient underwent elective ureteropelvic junction repair for which we obtained his informed consent.

\section{Discussion}

The kidney is affected in $10 \%$ of all blunt abdominal trauma. It is the most frequent urinary organ to suffer injury in blunt trauma. Ureteral injuriesfromexternal traumaareunusual, butwhentheyoccur, theyare usually related to penetrating trauma, primarily gunshot wounds (2). As with all cases of penetrating trauma, multiple associated intraabdominal organ injuries are often present. Missile paths that are in proximity to the ureter can also cause significant tissue damage and may have a delayed presentation. Blunt trauma usually affects the UPJ and is related to rapid deceleration injury (2).

Abnormal kidneys, including hydronephrotic kidneys, ectopic kidneys, and horseshoe kidneys as well as kidneys containing neoplasms or cysts, may sustain injury secondary to minor trauma (3). The occult unilateral hydronephrotic kidney is often discovered during the genitourinary evaluation of patients with abdominal trauma. The large size of a dilated renal pelvis itself may make it prone to

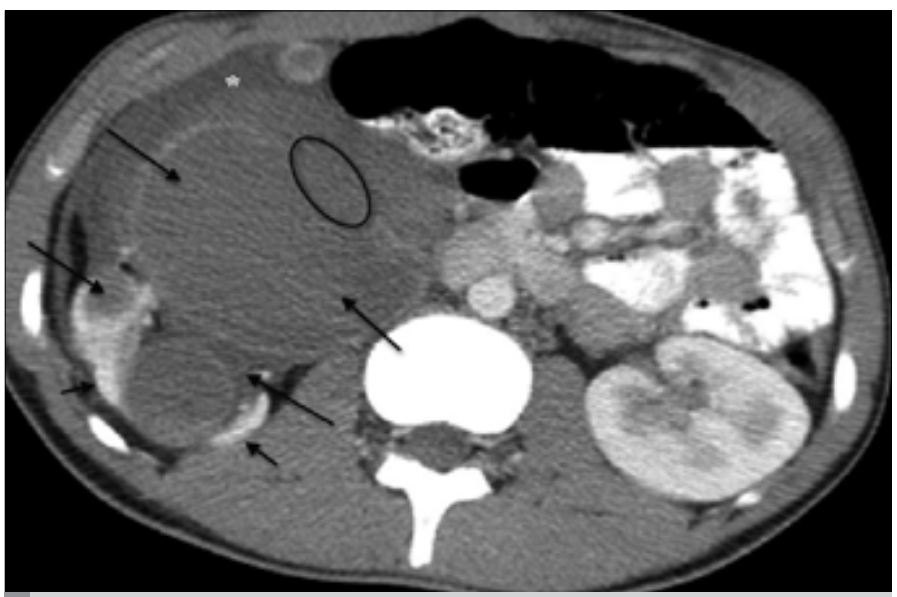

Figure 1. Contrast enhanced computed tomography demonstrates severe pelvicalyceal ectasia (long arrows), thinned cortex (short arrows) and large urinoma (asteriks) due to ruptured pelvis (in circle) injury because of its altered position within the body cavity, since it may no longer be protected from an external force by the rib cage or surrounding organs, as it was in the present case. Furthermore, a dilated renal pelvis may not be able to withstand an external force in the same way as a normal pelvis (4).

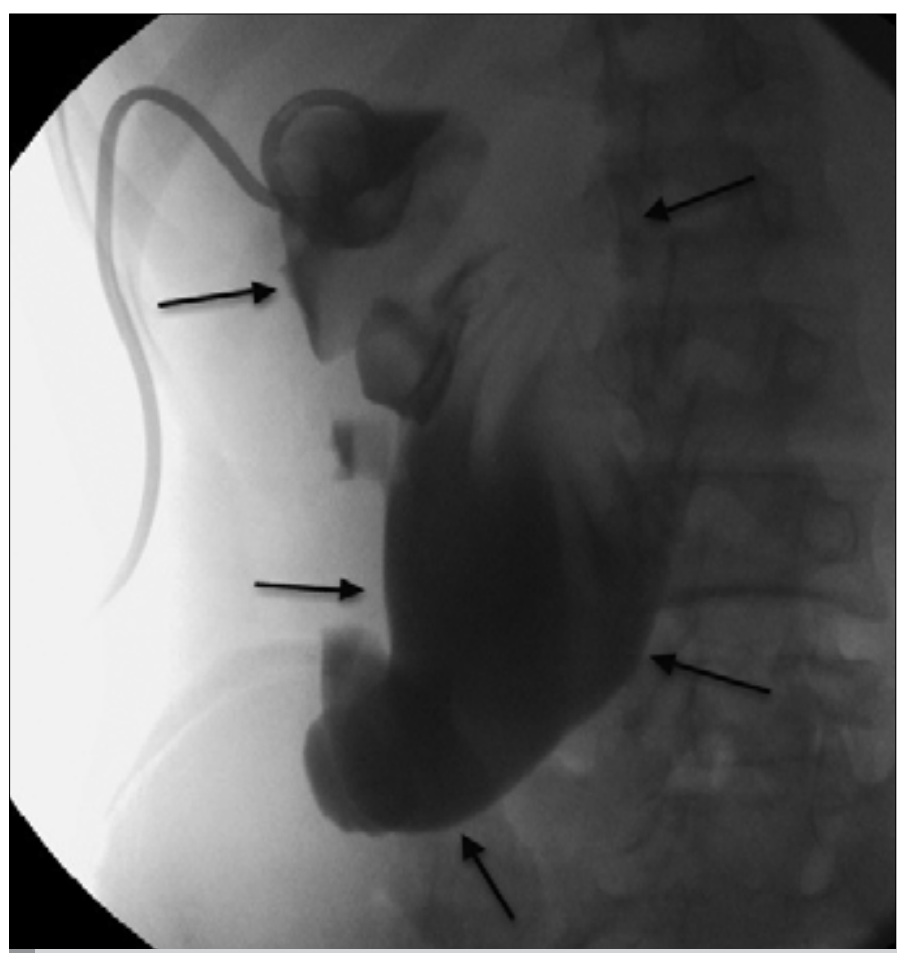

Figure 2. Antegrade pyelography performed through the nephrostomy catheter demonstrates immense extravasation of contrast through the ruptured renal pelvis (arrows)

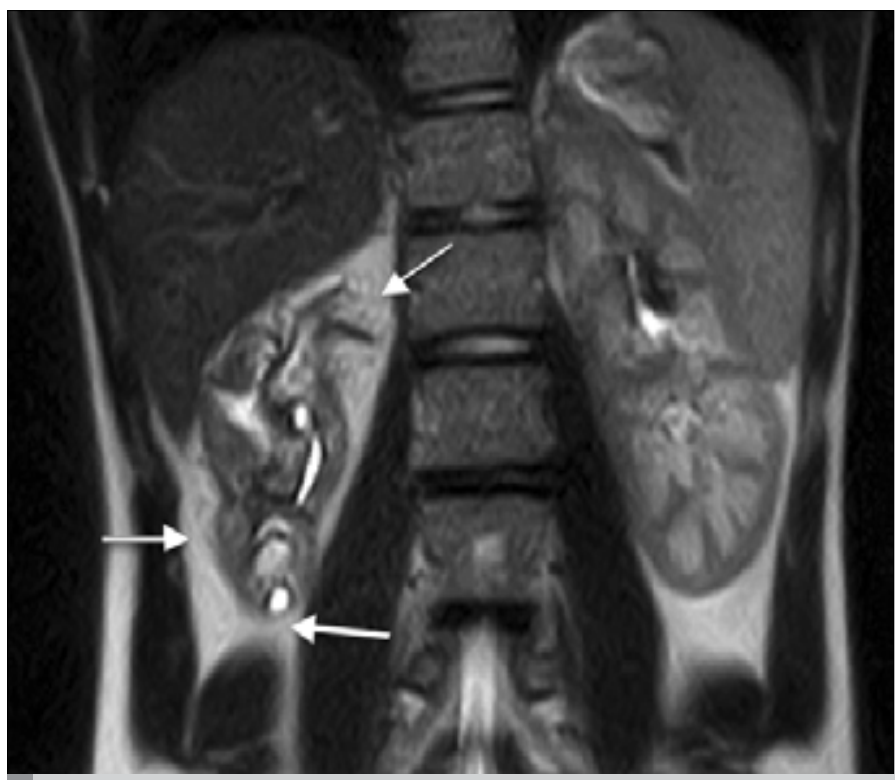

Figure 3. Coronal T2-weighted scan demonstrates resorption of urinoma in the right perirenal space (arrows) 
Preoperative imaging may not be performed in patients who are haemodynamically unstable and are usually taken directly to surgery. A rapid intravenous urogram (IVU) can be performed and this single radiograph may show contrast extravasation (5). Although US is often used in the diagnosis of medical renal disease and for rapid evaluation of the peritoneal cavity for free fluid, it is relatively insensitive in the detection of renal lacerations and contusions, extravasation of blood or urine, collecting system disruption and parenchymal haematoma. US revealed massive free fluid accompanying hydronephrosis, but was not effective for the differentiation of blood and urine in our case. A positive ultrasound was more likely with higher grades of renal injury, but a negative renal ultrasound had a very low negative predictive value (6).

The advent of CT in the trauma unit, and nearly universal use of CT, has altered our assessment of urinary tract trauma. Haematuria has been shown to be the best indicator of urinary tract injury, but it is an unreliable indicator of ureteral trauma and may be absent in many patients. However, the decision to perform CT has little to do with the presence or absence of hematuria (2).

In a study of 4,320 trauma patients who had undergone US, 33 of 99 patients with urologic injury had false negative US. The sensitivity was only $56 \%$ for those with isolated urologic injury (7). US is also not capable of grading renal injuries. CT has excellent negative predictive value for renal injury. The presence and type of renal injury can be accurately indicated (8). Renal contusion demonstrates ill-defined regions of diminished enhancement. Segmental renal infarction is identified as a wedge shaped area of non-enhancement, and renal artery occlusion can be accurately diagnosed by its complete lack of enhancement or excretion by the kidney. When a renal laceration is detected on contrast enhanced CT, a 10-minute delayed scan should be obtained to assess the urinary tract for urine leaks. Moreover delayed images are also helpful for characterizing the nature of a perinephric fluid collection and for distinguishing a hematoma from an urinoma (9). CT is excellent for demonstrating the extent of a hematoma and evaluating enlargement on follow-up scans (8). Rupture of the renal pelvis was obviously demonstrated in our case, therefore it did not require delayed scans to assess the urinary tract for urine leaks.

In patients with suspected UPJ injury, A CT with delayed phase imaging is a reliable tool for assessment. CT can also diagnose UPJ avulsion or ureteral injury, demonstrating lack of opacification of the ureter, retroperitoneal water attenuation collections adjacent to the pelvis or ureter, and possibly extravasation of contrast on delay scans (8). The distinction is important because lacerations are managed with a ureteral stent, whereas transections require surgical repair (10).

\section{Conclusion}

The presence of abnormality in the kidney is often discovered in the course of abdominal trauma; in these cases, a relatively minor traumatic event can cause serious problems without clinical findings such as macrohematuria or shock. Imaging plays a critical role in the assessment of the urinary tract in such cases who have suffered also a simple blunt trauma. CT is the primary imaging technique used to evaluate the urinary tract for trauma.
Conflict of Interest: No conflict of interest was declared by the authors.

Peer-review: Externally peer-reviewed.

Informed Consent: Written informed consent was obtained from patients who participated in this case.

Author Contributions: Concept - N.P., A.B.; Design - A.B.; Supervision - N.P., M.B.; Funding - N.P.; Materials - N.P., A.B.; Data Collection and/or Processing - N.P., A.B., M.B.; Analysis and/or Interpretation - N.P., A.B.; Literature Review - M.B., A.B.; Writer - N.P., A.B.; Critical Review - M.B., A.B.

Financial Disclosure: The authors declared that this study has received no financial support.

Çıkar Çatışması: Yazarlar çıkar çatışması bildirmemişlerdir.

Hakem değerlendirmesi: Dış bağımsız.

Hasta Onamı: Yazılı hasta onamı bu olguya katılan hastalardan alınmıştır.

Yazar Katkıları: Fikir - N.P., A.B.; Tasarım - A.B.; Denetleme - N.P., M.B.; Kaynaklar - N.P.; Malzemeler - N.P., A.B.; Veri toplanması ve/veya işlemesi - N.P., A.B., M.B.; Analiz ve/veya yorum - N.P., A.B.; Literatür taraması M.B., A.B.; Yazıyı yazan - N.P., A.B.; Eleştirel İnceleme - M.B., A.B.

Finansal Destek: Yazarlar bu çalışma için finansal destek almadıklarını beyan etmişlerdir.

\section{References}

1. Schmidlin FR, Iselin CE, Naimi A, Rohner S, Borst F, Farshad M, et al. The higher risk of abnormal kidneys in blunt renal trauma. Scand J Urol Nephrol 1998; 32: 388-92. [CrossRef]

2. Brandes S, Coburn M, Armenakas N, McAninch J. Diagnosis and management of ureteric injury: an evidence-based analysis. BJU Int 2004; 94: 277-89. [CrossRef]

3. Rhyner P, Federle MP, Jeffrey RB. CT of trauma to the abnormal kidney. AIR Am J Roentgenol 1984; 142: 747-50. [CrossRef]

4. Hall SJ, Carpinito GA. Traumatic rupture of a renal pelvis obstructed at the ureteropelvic junction: case report. J Trauma 1994; 37: 850-2. [CrossRef]

5. Roberts RA, Belitsky P, Lannon SG, Mack FG, Awad SA. Conservative management of renal lacerations in blunt trauma. Can J Surg 1987; 30: 253-5.

6. McGahan JP, Richards JR, Jones CD, Gerscovich EO. Use of ultrasonography in the patient with acute renal trauma. J Ultrasound Med 1999; 18: 207-13.

7. McGahan PJ, Richards JR, Bair AE, Rose JS. Ultrasound detection of blunt urological trauma: a 6-year study. Injury 2005; 36: 762-70. [CrossRef]

8. Kawashima A, Sandler CM, Corl FM, West OC, Tamm EP, Fishman EK, et al. Imaging of renal trauma: A comprehensive review. Radiographics 2001; 221: 557-74. [CrossRef]

9. Stuhlfaut JW, Lucey BC, Varghese JC, Soto JA. Blunt abdominal trauma: Utility of 5-minute delayed CT with a reduced radiation dose. Radiology 2006; 238: 473-9. [CrossRef]

10. Ramchandani P, Bucker PM. Imaging of genitourinary trauma. AJR Am J Roentgenol 2009; 192: 1514-23. [CrossRef] 